\title{
FAKTOR-FAKTOR YANG MEMPENGARUHI TINGKAT PERILAKU HIDUP BERSIH DAN SEHAT PADA TATANAN RUMAH TANGGA DI WILAYAH KERJA PUSKESMAS PONED $X$
}

\author{
Gita Sekar P., Lista D. A. ${ }^{2}$, Habibi R ${ }^{2}$, Arsinta I. I. ${ }^{2}$, Hanggara S. P. ${ }^{2}$, Galih R. P. ${ }^{2}$ Sinta F. ${ }^{3}$ \\ ${ }^{1}$ Bagian Ilmu Kesehatan Masyarakat Fakultas Kedokteran UMM \\ ${ }^{2}$ Mahasiswa Fakultas Kedokteran Fakultas Kedokteran UMM
}

Email : gitasekarprihanti@gmail.com

\begin{abstract}
ABSTRAK
Latar Belakang: PHBS merupakan salah satu strategi pemerintah untuk mencapai tujuan pembangunan kesehaatan. Faktorfaktor yang mempengaruhi perilaku hidup sehat yaitu faktor predisposisi, faktor pemungkin dan Faktor penguat. Laporan tahunan pada tahun 2015 di puskesmas X, didapatkan data cakupan rumah tangga yang melakukan kegiatan Perilaku Hidup Bersih dan Sehat (PHBS) di wilayah kerja puskesmas poned X sekitar 48,2\% masih belum mencapai target nasional pada tahun 2014 sebesar 70\%Metode: Desain penelitian cross sectional. Pengambilan sampel dengan teknik purposive sampling. Jumlah sampel 380 orang. Pelaksanaan penelitian dilakukan di 5 kelurahan di wilayah kerja puskesmas X. Hasil Penelitian:Berdasarkan hasil kuesioner didapatkan jumlah responden yang tidak berprilaku PHBS rumah tangga sebanyak 227 orang (59.7\%), sedangkan jumlah berprilaku PHBS rumah tangga sebanyak 153 orang (40.3\%). Hasil analisis multivariate regresi logistik didapatkan hubungan yang signifikan antara usia dengan tingkat perilaku PHBS rumah tangga $(p=0,003)$ serta tingkat pengetahuan dengan tingkat perilaku PHBS rumah tangga $(p=0,000)$, dan tidak didapatkan hubungan yang signifikan antara pendidikandengan tingkat perilaku PHBS rumah tangga $(\mathrm{p}=0,206)$. Kesimpulan: Terdapat hubungan antara usia dan tingkat pengetahuan dengan perilaku PHBS rumah tangga, sedangkan tidak terdapat hubungan antara pendidikandengan perilaku PHBS rumah tangga.
\end{abstract}

Kata Kunci: PHBS rumah tangga, usia, pengetabuan, pendidikan

ABSTRACT

Background: Clean and healthy behaviors is one of the government's strategy of the Ministry of Health to achieve Millennium development goal in 2015. Factors that influence health behavior is divided into 3 parts there are predisposing factors, enabling factors and reinforcing factors. Annual report 2015 in the public bealth centerof X, the data obtained domestic coverage conducting Clean and Healtby Behavior (PHBS) in the working area of the public bealth centerof $X$ about 48.2\% bas yet to reach the national target by 2014 by 70\%. Methods:Cross sectional study design. Sampling with purposive sampling technique. The total sample of 380 people. The research was carried in five villages in the region of puskesmas XResults: Based on the results of the questionnaire obtained the number of respondents who do not behave PHBS households by 227 people (59.7\%), while the number of PHBs behave households by 153 people $(40.3 \%)$. The results of the analysis of multivariate logistic regression found a significant correlation between age and the level of behavior PHBS household $(p=0.003)$ as well as the level of knowledge at the behavioral level PHBS household $(p=0.000)$, and there is no significant relationship between education and behavioral level PHBS home stairs $(p=0.206)$. Conclusion:There is a relationship between age and level of knowledge with PHBS behavior of households, while there is no relationship between education and household behavior PHBS

Key words: clean and healthy behaviors at the household, age, knowledge, education 


\section{PENDAHULUAN}

Masalah kesehatan yang ada di masyarakat sangatlah banyak dan beragam macamnya. Penelusuran dari rumah ke rumah merupakan cara paling efektif untuk mengetahui secara nyata masalah kesehatan yang sebenarnya dihadapi oleh masyarakat.Sebagian masyarakat ada yang menyadari bahwa ada masalah kesehatan yang sedang dialami dan sebagian masyarakat juga ada yang tidak menyadari bahwa terdapat masalah kesehatan yang dialami (Nurhajati, 2014).

Perilaku Hidup Bersih dan Sehat (PHBS) adalah sekumpulan perilaku yang dipraktikan atas dasar kesadaran sebagai hasil pembelajaran, yang menjadikan seseorang, keluarga, kelompok atau masyarakat mampu menolong dirinya sendiri (mandiri) di bidang kesehatan dan berperan aktif dalam mewujudkan kesehatan masyarakat. PHBS merupakan salah satu strategi pemerintah Departemen Kesehatan untuk mencapai tujuan pembangunan Millenium 2015 melalui rumusan visi dan misi Indonesia Sehat (Depkes, 2007).

Menurut Lawrence Green, faktor-faktor yang mempengaruhi perilaku hidup sehat dibagi menjadi 3 bagian yaitu faktor predisposisi (Umur, Tingkat Pengetahuan masyarakat dan tingkat pendidikan masyarakat), faktor pemungkin (fasilitas dan sarana) dan Faktor penguat (Dukungan Tokoh masyarakat, perilaku petugas kesehatan, dan tersamapaikan atau tidaknya promosi kesehatan PHBS terhadap masyarakat tersebut) (Green, 2005).

Sedangkan menurut Notoadmojo, Tingkat Pengetahuan dan Sikap Masyarakat ternyata sangat berpengaruh dengan Perilaku Hidup Bersih dan Sehat. Hal ini sudah dibuktikan melalui penelitian oleh Desi. Selain itu, pada penelitian Desi juga dibuktikan bahwa terdapat hubungan yang signifikan antara pekerjaan dengan Perilaku Hidup Bersih dan Sehat. (Notoadmojo, 2007).

Berdasarkan hasil Riskedas (Riset kesehatan dasar) tahun 2007 dapat diketahui, bahwa rumah tangga yang telah mempraktikan Perilaku Hidup Bersih dan Sehat (PHBS) baru mencapai angka $38.7 \%$, sedangkan target yang harus dicapai oleh Kementrian Kesehatan yaitu sebesar 70\% rumah tangga sudah mempraktikkan PHBS pada tahun 2014 (Kemekes, 2011).

Menurut laporan tahunan pada tahun 2015 di puskesmas X, didapatkan data cakupan rumah tangga yang melakukan kegiatan Perilaku Hidup Bersih dan Sehat (PHBS) di wilayah kerja puskesmas poned X sekitar 48,2\% masih belum mencapai target nasional pada tahun 2014 sebesar 70\% (Data Puskesmas X, 2015).

Penelitian yang dilakukan Damiyanti (2014) mendapatkan 17 respondenyang memiliki pengetahuan tinggi didapatkan 16 responden (94,1\%) Ibu Rumah Tangga menerapkan PHBS dan 1 responden (5,9\%) Ibu Rumah Tangga yang tidak menerapkan PHBS, sedangkan dari 28 responden yang memiliki pengetahuan rendah didapatkan 4 responden (14,3\%) Ibu Rumah Tangga menerapkan PHBS dan 24 responden (85,7\%) Ibu Rumah Tangga tidak menerapkan PHBS. Penelitian ini secara statistik didapatkan ada hubungan yangbermakna antara pengetahuan dengan Perilaku HidupBersih dan Sehat (PHBS) di Kelurahan Laing Wilayah Kerja Puskesmas Nan Balimo Kecamatan Tanjung Harapan Kota Solok Tahun 2014 (Damiyanti, 2014).

Dari latar belakang di atas, menyatakan betapa pentingnya perilaku untuk hidup bersih dan sehat terutama pada tatanan ruah tangga di wilayah kerrja puskesmas poned $\mathrm{X}$, maka penulis tertarik untuk mengadakan penelitian tentang faktor-faktor yang mempengaruhi tingkat perilaku hidup bersih dan sehat pada tatanan rumah tangga di wilayah puskesmas X.

\section{METODE}

Penelitian ini dilaksanakan di wilayah kerja Puskesmas Poned X, yang terdiri dari 5 kelurahan yaitu $\mathrm{X}$, dandangan, ngadirejo, semampir dan pocanan. Penelitian ini merupakan penelitian crosssectional dengan metode purposive sampling, yang dilakukan pada bulan Agustus 2016.

Sampel penelitian ini berjumlah 360 ibu rmah tangga. Kriteria inklusi adalah setiap ibu rumah tangga yang bertempat tinggal tetap di wilayah kerja puskesmas poned $\mathrm{X}$ dan bersedia mengisi kuisioner penelitian, ibu rumah tangga yang sudah menikah dan mempunyai anak, setiap rumah tangga diwakilkan oleh salah satu anggota keluarga yaitu ibu rumah tangga untuk pengisian kuesioner. Kriteria eksklusinya yaitu responden yang menolak mengisi angket.

Subjek penelitian adalah setiap keluarga yang diwakili oleh ibu rumah tangga pada tiap keluarga 
yang bertempat tinggal di 5 kelurahan di wilayah kerja puskesmas poned X.

Pengambilan data kepada responden melalui kuesioner penelitian yang diberikan kepada responden. Responden diambil secara acak pada kelima kelurahan tersebut. Responden diberikan kuesioner untuk menentukan usia, tingkat pendidikan serta tingkat pengetahuan serta tingkat perilaku PHBS yang telah dilakukan selama ini.

Usia dari ibu rumah tangga dihitung dari tanggal lahir sampai tanggal saat dilakukan penelitian ini. Usia dikelompokkan berdasarkan 21 - 30tahun, 31 - 40tahun dan > 40tahun(Suryani, 2009).

Pendidikan terakhir yang ditempuh oleh responden yang nantinya dibagi dalam kelompok dasar, menengah dan tinggi. SD-SMP dikelompokkan pada pendidikan dasar, SMA pada pendidikan menengah dan Diploma/Sarjana pada pendidikan tinggi (Roni,2013).

Pengetahuan masyarakat dalam memahami konsep PHBS dalam rumah tangga yang dinyatakan dalam 10 poin pertanyaan pilihan ganda. Setelah didapatkan hasil akan dinilai secara statistik dan dikelompokkan ke dalam 3 kelompok yaitu pengetahuan kurang, cukup dan baik. Pengetahuanbaik; bila skor $>$ mean +standar deviasi, pengetahuan cukup;bila skor $>$ mean standar deviasi dan <Mean+standardeviasi, pengetahuankurang;bila skor <meanstandardeviasi. (Haniek, 2011).

Tingkat perilaku PHBS merupakan terlaksananya program PHBS di rumah tangga di tiap keluarga dengan mengedepankan terlaksananya 10 indikator PHBS rumah tangga yang dinyatakan dalam 10 poin pertanyaan yang mempunyai jawaban ya dan tidak. Keluarga yang dianggap melakukan perilaku PHBS jika menjawab ya kesepuluh indikator PHBS rumah tangga jika salah satu saja ada yang menjawab tidak maka dianggap tidak berperilaku PHBS rumah tangga (Kemenkes, 2011).

Hasil penelitian akan dilakukan uji dengan menggunakan analisis bivariat (uji chi square) dan multivariat (regresi logistik) menggunakan SPSS 21 for windows.
HASIL

Penelitian dilakukan di wilayah kerja puskesmas poned $\mathrm{X}$. Kelurahan yang dibawah wilayah kerja puskesmas poned $\mathrm{X}$ ada 5 kelurahan diantaranya dandangan, ngadirejo, semampir, $\mathrm{X}$ dan pocanan. Jumlah keseluruhan keluarga yang tercatat adalah 7.788 keluarga. Sampel pada penelitian kali ini 380 keluarga yang diwakilkan oleh tiap ibu rumah tangga.

Tabel 1 karakteristik responden berdasarkan perilaku PHBS rumah tangga

\begin{tabular}{ccc}
$\begin{array}{c}\text { Karakteristik } \\
\text { Individu }\end{array}$ & $\begin{array}{c}\text { Perilaku } \\
\text { PHBS }\end{array}$ & $\begin{array}{c}\text { Pres entase } \\
(\%)\end{array}$ \\
\hline Tidak & 227 & $59.7 \%$ \\
Ya & 153 & $40.3 \%$ \\
Total & 380 & 100 \\
\hline
\end{tabular}

Dari tabel 1 dapat diketahui bahwa jumlah responden yang tidak berprilaku PHBS rumah tangga sebanyak 227 orang (59.7\%), sedangkan jumlah berprilaku PHBS rumah tangga sebanyak 153 orang (40.3\%).

Tabel 2 karakteristik responden berdasarkan usia

\begin{tabular}{lcccc}
\hline \multirow{2}{*}{$\begin{array}{c}\text { Karakteristik } \\
\text { Individu }\end{array}$} & \multicolumn{2}{c}{ Tidak PHBS RT } & \multicolumn{2}{c}{ Ber-PHBS RT } \\
\cline { 2 - 5 } & $\begin{array}{c}\text { Jumla } \\
\mathrm{h}\end{array}$ & $\begin{array}{c}\text { Prosenta } \\
\text { se }(\%)\end{array}$ & Jumlah & $\begin{array}{c}\text { Prosenta } \\
\text { se }(\%)\end{array}$ \\
\hline Umur & & & & \\
$21-30$ tahun & 45 & 19.8 & 39 & 25.5 \\
$31-40$ tahun & 60 & 26.4 & 68 & 44.4 \\
$>40$ tahun & 122 & 53.7 & 46 & 30.1 \\
\hline Total & 227 & 100 & 153 & 100 \\
\hline
\end{tabular}

Berdasarkan tabel 2 dapat diketahui bahwa jumlah responden kelompok tidak ber-PHBS rumah tangga yang berusia 21 - 30 tahun sebanyak 45 orang (19.8\%), yang berusia 31 - 40 tahun sebanyak 60 orang $(26.4 \%)$ dan yang berusia $>40$ tahun sebanyak 122 orang (53.7\%). Sedangkan pada keluarga yang berprilaku PHBS rumah tangga yang 21 - 30 tahun sebanyak 39 orang (25.5), yang berusia 31 - 40 tahun sebanyak 68 orang (44.4\%) dan yang berusia $>40$ tahun sebanyak 46 orang $(30.1 \%)$. 
Tabel 3 karakteristik responden berdasarkan pendidikan

\begin{tabular}{lcccc} 
Karakteristik \begin{tabular}{c} 
Individu \\
\cline { 2 - 5 }
\end{tabular} & \multicolumn{2}{c}{ Tidak PHBS RT } & \multicolumn{2}{c}{ Ber-PHBS RT } \\
\cline { 2 - 5 } & Jumlah & $\begin{array}{l}\text { Prosenta } \\
\text { se (\%) }\end{array}$ & $\begin{array}{l}\text { Juml } \\
\text { ah }\end{array}$ & $\begin{array}{l}\text { Prosenta } \\
\text { se (\%) }\end{array}$ \\
\hline Dasar & 110 & 48.5 & 40 & 26.1 \\
Menengah & 94 & 41.4 & 78 & 51 \\
Tingi & 23 & 10.1 & 35 & 22.9 \\
\hline Total & 227 & 100.0 & 153 & 100.0
\end{tabular}

Berdasarkan tabel 3 dapat diketahui bahwa jumlah responden kelompok tidak ber-PHBS rumah tangga yang berpendidikan dasar sebanyak 110 orang (48.5\%), yang berpendidikan menengahsebanyak 94 orang $(41.4 \%)$ dan yang berpendidikan tinggi sebanyak 23 orang (10.1\%). Sedangkan pada keluarga yang berprilaku PHBS rumah tangga yang berpendidikan dasar sebanyak 40 orang (26.1\%), yang berpendidikan menengahsebanyak 78 orang $(51 \%)$ dan yang berpendidikan tinggi sebanyak 35 orang $(22.9 \%)$.
Tabel 4 karakteristik responden berdasarkan pengetahuan

\begin{tabular}{lcccc}
\hline Karakteristik & \multicolumn{2}{c}{ Tidak PHBS RT } & \multicolumn{2}{c}{ Ber-PHBS RT } \\
\cline { 2 - 5 } & $\begin{array}{l}\text { Jumlividu } \\
\text { h }\end{array}$ & $\begin{array}{l}\text { Prosentas } \\
\text { e (\%) }\end{array}$ & $\begin{array}{l}\text { Juml } \\
\text { ah }\end{array}$ & $\begin{array}{l}\text { Prosenta } \\
\text { se (\%) }\end{array}$ \\
\hline Kurang & 58 & 25.6 & 8 & 5.2 \\
Cukup & 147 & 64.8 & 96 & 62.7 \\
Baik & 22 & 9.7 & 49 & 32 \\
\hline Total & 227 & 100.0 & 153 & 100.0
\end{tabular}

Berdasarkan tabel 5.1.5 dapat diketahui bahwa jumlah responden kelompok tidak ber-PHBS rumah tangga yang berpengerahuan kurang sebanyak 58 orang $(25.6 \%)$, yang berpengerahuan cukup sebanyak 147 orang (64.8\%) dan yang berpengerahuan baik sebanyak 22 orang (9.7\%). Sedangkan pada keluarga yang berprilaku PHBS rumah tangga yang berpengerahuan kurang sebanyak 8 orang $(5.2 \%)$, yang berpengerahuan cukup sebanyak 96 orang $(62.7 \%)$ dan yang berpengerahuan baik sebanyak 49 orang $(32 \%)$.

\section{Analisis Bivariat}

Berikut ini akan dijelaskan mengenai analisis hubungan antar dua variabel. Pengujian analisis dilakukan dengan menggunakan uji chi square.

\begin{tabular}{cccccc}
\hline \multirow{2}{*}{ Variabel } & \multirow{2}{*}{ Kategori } & \multicolumn{2}{c}{ Perilaku PHBS Rumah } & \multirow{2}{*}{ Tangga } & \multirow{2}{*}{ Potal } \\
\cline { 3 - 4 } & & Tidak & Ya & & \\
\cline { 3 - 4 } Usia & $21-30$ tahun & $45(11.8 \%)$ & $39(10.3 \%)$ & $84(22.1 \%)$ & \\
& $31-40$ tahun & $60(15.8 \%)$ & $68(17.9 \%)$ & $128(33.7 \%)$ & $(p)$ sebesar \\
& $>40$ tahun & $122(32.1 \%)$ & $46(12.1 \%)$ & $168(44.2 \%)$ & 0,000 \\
\hline Pendidikan & Dasar & $110(28.9 \%)$ & $40(10.5 \%)$ & $150(39.5 \%)$ & \\
& Menengah & $94(24.7 \%)$ & $78(20.5 \%)$ & $172(45.3 \%)$ & $(p)$ sebesar \\
& Tinggi & $23(6.1 \%)$ & $35(9.2 \%)$ & $58(15.3 \%)$ & 0,000 \\
\hline \multirow{2}{*}{ Pengetahuan } & Kurang & $58(15.3 \%)$ & $8(2.1 \%)$ & $66(17.4 \%)$ & \\
& Cukup & $147(38.7 \%)$ & $96(25.3 \%)$ & $243(63.9 \%)$ & $(p)$ sebesar \\
& Baik & $22(5.8 \%)$ & $49(12.9 \%)$ & $71(15.3 \%)$ & 0,000 \\
\hline
\end{tabular}

Adjusted R square value $0,076 \%$

Berdasarkan tabel 5 dapat diketahui bahwa diperoleh nilai probabilitas (sig) sebesar 0,000. Karena nilai probabilitas (sig) $<0,05$ maka dapat dinyatakan bahwa $\mathrm{H}_{0}$ ditolak yang berarti bahwa terdapat hubungan yang signifikan antara usia dengan Tingkat perilaku PHBS rumah tangga. 
Berdasarkan tabel 5 dapat diketahui bahwa diperoleh nilai probabilitas (sig) sebesar 0,000 . Karena nilai probabilitas (sig) $<0,05$ maka dapat dinyatakan bahwa $\mathrm{H}_{0}$ ditolak yang berarti bahwa terdapat hubungan yang signifikan antara tingkat pendidikan dengan tingkat perilaku PHBS rumah tangga

Berdasarkan tabel 5 dapat diketahui bahwa diperoleh nilai probabilitas (sig) sebesar 0,000 . Karena nilai probabilitas (sig) $<0,05$ maka dapat dinyatakan bahwa $\mathrm{H}_{0}$ ditolak yang berarti bahwa terdapat hubungan yang signifikan antara tingkat pengetahuan dan perilaku PHBS rumah tangga.

Berdasarkan nilai adjusted $R$ square yaitu 0,076 $(7,6 \%)$ maka menunjukkan bahwa faktor yang mempengaruhi tingkat PHBS rumah tangga sebesar 7,6 \% dapat dijelaskan oleh tiga variabel yang berhubungan tersebut sisanya ditentukan oleh faktor lain yang tidak diteliti.

Crude odds ratio atau OR adalah besarnya resiko variabel bebas terhadap variabel terikat, dan besaran nilai OR didapat dengan melakukan analisis bivariat, sedangkan untuk mengetaui tingkat kemaknaannya dengan melakukan uji chi-square. Hasil analisis bivariat dengan nilai crude OR masingmasing faktor resiko dijelaskan pada table 5 dan 6 (Dahlan, 2011).
Pada table 6 terlihat bahwa faktor usia dan pengetahuan merupakan faktor yang mempengaruhi tingkat perilaku PHBS rumah tangga setelah dilakukan analisis regresi logistik yang mana pendidikan akhirnya tidak dimasukkan menjadi faktor yang paling berpengaruh dibandingkan usia dan tingkat pengetahuan.

Pada tabel 6 didapatkan hasil analisis multivariat dengan regresi logistik. Usia (1) adalah usia 20-31 tahun, usia (2) adalah 31-40 tahun sedangkan usia $>40$ tahun sebagai pembanding. Pengetahuan (1) adalah pengetahuan kurang, pengetahuan (2) adalah pengetahuan cukup sedangkan pengetahuan baik digunakan sebagai pembanding.

Secara statistik menunjukkan bahwa faktor usia 31-40 tahun yang dibandingkan dengan usia $>40$ tahun merupakan salah satu faktor resiko yang mempengaruhi tingkat perilaku PHBS rumah tangga (OR:2.384, CI 95\%: 1.416-4.013, P: 0.001). Faktor selanjutnya yang berpengaruh adalah faktor usia 2130 tahun yang dibandingkan dengan usia $>40$ tahun (OR: 1.997, CI 95\%: 1.115-3.576, P: 0.020). faktor berikutnya adalah faktor pengetahuan kurang dibandingkan faktor pengetahuan baik (OR: 0.079, CI 95\%: 0.032-0.196, P: 0.000).

Tabel 6 Hasil Analisis Data Multivariat

\begin{tabular}{lccccc}
\hline \multirow{2}{*}{ Variabel } & \multirow{2}{*}{ B } & \multirow{2}{*}{ OR } & & \multicolumn{2}{c}{ CI 95\% } \\
\cline { 1 - 1 } \cline { 5 - 6 } & & & & Lower & Upper \\
\hline Usia (1) & 0.691 & 0.020 & 1.997 & 1.115 & 3.576 \\
\hline Usia (2) & 0.869 & 0.001 & 2.384 & 1.416 & 4.013 \\
\hline Pengetahuan (1) & -2.538 & 0.000 & 0.079 & .032 & .196 \\
\hline Pengetahuan (2) & -1.264 & 0.000 & 0.282 & .159 & .503 \\
\hline Constant & 0.323 & & & & \\
\hline
\end{tabular}

Berdasarkan nilai koefesien masing-masing variable diperoleh persamaan regresi logistic :

Logit $(\mathrm{y})=0.323+0.691$ (Usia 21-30 tahun) + 0.869 (usia 31-40 tahun) $+(-2.538)$ (Pengetahuan kurang) $+(-1.264)$ (pengetahuan cukup)

Aplikasi dari persamaan yang diperoleh adalah untuk memprediksi faktor faktor apa sajakah yang dapat mempengaruhi perilaku PHBS rumah tangga dengan menggunakan rumus:

$$
\mathrm{P}=1 /\left(1+\mathrm{e}^{-\mathrm{y}}\right)
$$

Dari persamaan diatas akan didapatkan 4 probabilitas yang terjadi. Probabilitas pertama jika seorang dengan usia 21-30 tahun dan pengetahuan cukup maka probabilitas untuk tidak melakukan PHBS rumah tangga sebesar 56\%. Probabilitas kedua jika seorang dengan usia 21-30 tahun dan pengetahuan kurang maka probabilitas untuk tidak melakukan PHBS rumah tangga sebesar 81\%. Probabilitas ketiga jika seorang dengan usia 31-40 
tahun dan pengetahuan cukup maka probabilitas untuk tidak melakukan PHBS rumah tangga sebesar 51\%. Probabilitas keempat jika seorang dengan usia 31-40 tahun dan pengetahuan kurang maka probabilitas untuk melakukan PHBS rumah tangga sebesar $79 \%$.

Berdasarkan hasil penghitungan dan persamaan regresi logistik di atas yang diolah dengan menggunakan program SPSS, maka dapat disimpulkan bahwa pada variabel usia, dimana usia 31-40 $\operatorname{tahun}(\hat{\mathrm{a}}=0,869)$ memiliki resiko untuk mempengaruhi tingkat perilaku PHBS rumah tangga sebesar 2,384 kali lipat daripada usia selain 31-40 tahun, dimana nilai CI antara 1,416 hingga 4,013.

Pada variabel peran pengetahuan, dimana pengetahuan yang kurang ( $\hat{a}=-2.538)$ memiliki resiko dalam mempengaruhi tingkat perilaku PHBS rumah tangga sebesar 0,079 kali lipat dibandingkan pengetahunan yang cukup dan baik. Dimana nilai CI antara 0,032-0,196.

\section{PEMBAHASAN}

Dari hasil penelitian dengan 380 sampel ibu rumah tangga yang mewakili masing-masing keluarga di 5 kelurahan wilayah kerja puskesmas poned X didapatkan faktor yang berpengaruh terhadap tingkat perilaku PHBS adalah usai dan pengetahuan sedangkan pendidikan tidak berpengaruh ketika dilakukan analisis regresi logistik.

Pengaruh usia terhadap perilaku PHBS sesuai dengan tabel 5 analisis bivariat dan analisis multivariat tabel 6 dengan nilai signifikansi sebesar $0,000(p<0,05)$ artinya usia memiliki pengaruh secara signifikan dalam mempengaruhi perilaku PHBS. Hal ini sesuai dengan penelitian yang dilakukan oleh Suryani (2009) yaitu dari 36 responden berusia 3140 tahun, 44,4\% atau sekitar 16 responden tidak melakukan perilaku PHBS rumah tangga, terdapat hubungan yang signifikan dengan $p=0,006$ dan OR 0,475 dengan CI 95\% 0,193-1,165. Hasil penelitian tersebut berbeda dengan yang dilakukan oleh Hapsari (2010)pada penelitiannya meneliti faktor yang mempengaruhi perilaku PHBS namun tidak mendapatkan hubungan yang signifikan dalam uji statistik dengan $p=0,406$. Menurut Iskriyanti (2002), umur merupakan suatu faktor yang dapat menggambarkan kematangan fisik, psikis ataupun sosial dan sekurang-kurangnya berpengaruh dalam proses pembelajaran.
Perubahan perilaku karena proses pendewasaan pada hakekatnya merupakan gabungan atau terjadi baik secara adaptif maupun naluriah. Melalui perjalanan umurnya yang semakin dewasa, makhluk yang bersangkutan akan melakukan adaptasi perilaku hidupnya terhadap lingkungannya disamping secara alamiah juga berkembang perilaku yang sifatnya naluriah untuk melakukan praktik hidup sehat (Budioro, 1998).

Selain semakin dewasanya umur juga didorong oleh motivasi individu tersebut untuk melakukan perilaku hidup bersih dan sehat dalam rumah tangga. Pada umur berapapun, jika seseorang sudah mempunyai dorongan yang kuat dari dalam diri individu tersebut maka praktik berperilaku hidup bersih dan sehat tersebut akan terwujud. Karena dorongan dalam diri individu dapat mewujudkan motivasi untuk melakukan suatu aktivitas. Atas dasar motivasi inilah maka perilaku hidup bersih dan sehat akan terbentuk (Slamet, 2003).

Pengaruh pendidikan terhadap perilaku PHBS sesuai dengan tabel 5 analisis bivariat dan analisis multivariat tabel 6 dengan nilai signifikansi sebesar $0,000(p<0,05)$ namun pada tabel analisis multivariat 5.3.1 nilai signifikansinya sebesar $p=0,206(p<0,05)$ dimana dinyatakan tidak ada hubungan yang signifikan antara pendidikan dengan tingkat perilaku PHBS rumah tangga.

Penelitian ini berbeda dengan penelitian Roni (2013) dimana mencari hubungan antara tingkat pendidikan serta penghasilan dengan perilaku hidup bersih dan sehat. Pada penelitian tersebut menunjukkan korelasi yang positif yang berarti kenaikan pada variabel pendidikan dan penghasilan diikuti oleh peningkatan perilaku hidup bersih dan sehat dengan nilai $p=0.000$ dan OR sebesar 0,528 . Teori yang dikemukakan Talcott Parson, bahwaperilaku dipengaruhi oleh sistem sosial, budaya, dankepribadian. Pendidikan dan penghasilan merupakansebagian unsur struktur sosial yang mempengaruhisistem sosial. Artinya pendidikan dan penghasilanmempengaruhi perilaku (Ritzer, 2005).

Pendidikan formal yang dimiliki seseorang akan mempengaruhi kemampuan untuk mencerna informasi - informasi yang diterima sekaligus mempertimbangkan apakah informasi tersebut bisa dijadikan dasar bagi perilakumereka selanjutnya. Dalam hal penerimaan pesan, seseorang yang memiliki pendidikan dasar biasanya lebih lambat jika dibandingkan dengan responden yang memiliki 
tingkat pendidikan menengah maupun tinggi. Oleh karena itu dalam penyampaian pesan diperlukan adanya suatu media sehingga dapat membantu seseorang dalam menerima pesan tersebut. Selain itu, dengan adanya perbedaan tingkat pendidikan maka akan berdampak pada berbedanya individu menanggapi suatu masalah dan penerimaan pesan lebih mudah bagi yang memiliki tingkat pendidikan yang lebih tinggi (Jumali, 2008).

Pengaruh pendidikan terhadap perilaku PHBS sesuai dengan tabel 5 analisis bivariat dan analisis multivariat tabel 6 dengan nilai signifikansi sebesar $0,000(p<0,05)$ artinya usia memiliki pengaruh secara signifikan dalam mempengaruhi perilaku PHBS. Sejalan dengan penelitian Mahfudah (2012) yang memperoleh hasil yang signifikan dalam penelitian antara pengetahuan dan perilaku PHBS.dan Damiyanti (2014) dengan nilai $\mathrm{p}=0,000$ serta OR sebesar 96.00 .

Pengetahuan dapat membentuk keyakinan tertentu sehingga seseorang berperilaku sesuai dengan keyakinan tersebut dengan pengetahuan kesehatan lingkungan yang baik diharapkan dapat meningkatkan kesadaran masyarakat akan pentingnya menciptakan kondisi lingkungan yang sehat, sehingga dapat memutuskan rantai penularan penyakit melalui lingkungan serta perilaku hidup bersih dan sehat agar tidak mudah tertular penyakit

Hal ini sesuai dengan Notoatmodjo (2007), tingkat pengetahuan seseorang atau keluarga sangat mempengaruhi PHBS. Dari hasil penelitian maka peneliti berasumsi bahwa ibu yang mempunyai pengetahuan baikmengenai perilaku hidup bersih dan sehat, ternyata memiliki perilaku hidup bersih dan sehat yang baik pada tatanan rumah tangga, sedangkan ibu yang pengetahuannya kurang baik mengenai perilaku hidup bersih dan sehat, ternyata memiliki perilaku hidup bersih dan sehat yang kurang baik pada tatanan rumah tangganya, karena itu ibu yang pengetahuannya baik cenderung lebih memperhatikan kebersihan rumah dan kesehatan keluarganya dibandingkan ibu yang kurang baik pengetahuannya cenderung tidak memperhatikan kebersihan dan kesehatan keluarga mereka.

\section{KESIMPULAN}

Penelitian ini menyimpulkan bahwa ada hubunganantara usia dan tingkat pengetahuan dengan tingkat perilaku hidup bersih dan sehat dengan nilai signifikansi sebesar $0,003(p<0,05)$ untuk faktor usia dan nilai signifikansi sebesar 0,000 $(p<0,05)$ untuk tingkat pengetahuan. Sedangkan pendidikan tidak ada hubungan dengan tingkat perilaku hidup bersih dan sehat.

Saran untuk penelitian selanjutnya adalah mencari faktor-faktor lain selain yang diteliti dikarenakan masih banyak faktor lain yang ikut mempengaruhi tingkat perilaku hidup bersih dan sehat dalam rumah tangga selain 3 faktor yang diteliti dalam penelitian ini.

\section{REFERENSI}

Budioro, 1998, PengukurPendidikan (Penyuluban) Kesehatan Masyarakat, Semarang: Undip Press.

Dahlan, Sopiyudin., 2011. Statistik Untuk Kedokteran dan Kesehatan Edisi 5.Jakarta, Salemba Medika.

Damiyanti, S. Crisni, H. 2014. Hubungan Pengetahuan Ibu Rumah Tangga DanPeran Kader Dengan Perilaku Hidup Bersih DanSehat (Phbs) Dalam Rumah Tangga Di KelurahanLaing Wilayah Kerja Puskesmas NanBalimo Kecamatan TanjungHarapan Kota SolokTahun 2014. LPMM Stikes Yarsi

Data puskesmas X. 2015. Laporan tahunan 2015. UPTD Puskesmas Poned X .

Departemen Kesehatan RI, 2007. Buku Saku Rumah Tangga Sehat dengan PHBS, Pusat Promosi Kesehatan, Jakarta.

Green, W, Lawrence.et.al. 2005. Health Education Planing A Diagnostik Approach, The Johns Hapkins University. Mayfield Publishing Company.

Haniek, Hilya. 2011. Hubungan Antara Pengetahuan Dan SikapDengan Perilaku Hidup Bersih Dan SehatPada Ibu Rumah Tangga Di KecamatanLubuk Sikaping Tahun 2011. Jakarta. UIN Jakarta.

Iskriyanti, Hari. 2002, Hubungan Karakteristik, Pengetahuan dan Sikap Ibu Rumah Tangga Tentang PHBS Dengan Praktek Kesehatan Keluarga dan Kesehatan Lingkungan di Kelurahan Rejowinangun Kecamatan Kota Gede Kota Yogyakarta Agustus 2002. Semarang :UNDIP

Jumali Asroh, 2008, Analisis Faktor Yang Berhubungan Dengan Rendahnya Cakupan Imunisasi DPT Pada Bayi Usia 2 - 11 Bulan 


\section{VOLUME 14 NOMOR 1 JUNI 2018}

Di Wilayah Kerja Puskesmas Kebumen III Kabupaten Kebumen Tahun 2008. Semarang. Unnes

Kementrian Kesehatan. 2011.Panduan Peningkata PerilakuHidup Bersih dan Sehat dan Rumah tangga. Pusat Promosi Kesehatan Departemen Kesehatan RI. Jakarta.

Mahfudhah, Desi. 2012. Hubungan Pengetahuan, Sikap Dan Pekerjaan Ibu TerhadapPerilaku Hidup Bersih Dan Sehat Pada Tatanan RumahTangga Di Desa Reukih Dayah Kecamatan Indrapuri Kabupaten Aceh Besar. Stikes Ubudiyah Banda Aceh.

Notoatmodjo, S 2007, Ilmu Kesehatan Masyarakat, Jakarta : PT. Rineka Cipto

Notoatmodjo, S. 2007. Pendidikan dan Perilaku kesehatan. Cetakan 2 jakarta: PT. RinekaCipta

Nurhajati, Nunun. 2014. Perilaku Hidup Bersih dan Sehat (PHBS) Masyarakat Desa Samir Dalam Meningkatkan Kesehatan Masyarakat. Jurnal Unita. Hal.1-18.

Ritzer, George, Douglas J. Goodman. 2007. Teori Sosiologi Modern. Jakarta: Kencana.

Roni, T. Tati, R. Denny, S. 2013. Hubungan Pendidikan Dan Penghasilan Dengan Perilaku Hidup Bersih Dan Sehat. Jurnal Kesehatan Lingkungan Indonesia Vol. 12 no. 1. Hal 2226.

Slamet, M. 2003. Membentuk Pola Perilaku Manusia Pembangunan. IPB Press. Bogor.

Suriyani, 2009. Faktor-Faktor Yang Mempengaruhi Pelaksanaan Program Promosi Kesehatan Rumah TanggaYang Sehat Di Wilayah Kerja Puskesmas Teladan Medan Kecamata Medan Kota Tahun 2009. Tesis. Medan. USU 